\title{
Perancangan Sistem Penulisan Teks pada Running text Menggunakan SMS
}

\author{
Octarina Nur Samijayani, Rahsanjani, Fadjar Iftikhar \\ Program Studi Teknik Elektro, Fakultas Sains dan Teknologi \\ Universitas Al Azhar Indonesia, Jl. Sisingamangaraja, Jakarta, 12110 \\ Penulis untuk korespondensi/E-mail: octarina.nur@uai.ac.id
}

\begin{abstract}
Abstrak - Teknologi yang dinilai efisien digunakan untuk menyampaikan informasi di tempat-tempat umum adalah menggunakan papan running text. Penulisan teks yang akan dikirim ke running text saat ini mengandalkan peranti komputer ataupun remote. Peranti komputer akan dihubungkan dengan kabel ke papan running text sehingga harus tersedia komputer di dekat tampilan running text, sedangkan secara wireless digunakan remote namun memiliki jarak yang terbatas. Dengan memanfaatkan modul GSM sebagai transceiver penulisan teks dari jarak jauh melalui SMS dapat dilakukan. Penulisan teks melalui SMS dapat mendukung penulisan yang lebih efisien terutama untuk menyebarkan informasi yang sama pada beberapa lokasi running text, sehingga penulisan teks tidak lagi harus berada di dekat running text melainkan dapat dilakukan dipusat informasi yang jauh dari letak running text. Penulisan teks pada running text dilakukan melalui SMS dari ponsel, kemudian pesan diterima oleh modul GSM dan diteruskan ke mikrokontroller untuk menampilkan teks pada display running text. Uji coba dilakukan untuk mengukur waktu pengiriman teks sampai tulisan berhasil ditampilkan. Berdasarkan hasil uji coba, waktu pengiriman SMS berbanding lurus dengan jumlah karakter yang dikirimkan. Rata - rata waktu pengiriman teks menggunakan operator yang sama adalah sekitar 28.31 detik dan bila menggunakan operator yang berbeda adalah sekitar 31.20 detik. Sistem penulisan teks akan semakin cepat apabila digunakan operator GSM yang sama pada ponsel dan modul GMS di sisi display running text.
\end{abstract}

Abstract - The running text board technology is efficient in conveying information in public places. The writing of running text currently relies on a remote computer. Handheld computers is connected by cable to the running text and should be available near the display, while the use of wireless remote still has a limited distance. By utilizing the GSM module as a transceiver the writing of text can be done remotely via SMS. Text entry through SMS can support a more efficient writing primarily to broadcast the same information in multiple locations running text. So that the writing of text is no longer have to be near the display, but can be done from the information center which is far from the location of the display. Time needed from send SMS until the message is increasing according to the rising of SMS number characters. Average time needed from sending to displayed message when using same operators is $\mathbf{2 8 . 3 1}$ seconds and $\mathbf{3 1 . 2 0}$ seconds when using different operators. The system will process the message from sending to display faster when using same GSM operators than different GSM operators.

Keywords - Notice board, GSM modem, SMS, LCD, microcontroller ATMEGA8535.

\section{PENDAHULUAN}

$\mathrm{M}$ engingat pentingnya sebuah media informasi bagi masyarakat di tempat-tempat umum mengenai aturan, pesan moral, jadwal keberangkatan hingga promo barang menjadi sebuah kebutuhan tersendiri bagi pemberi informasi dan penerima informasi. Semakin canggih teknologi saat ini semakin pula masyarakat ingin dimudahkan dalam menyelesaikan setiap pekerjaannya, salah satunya dalam penyampaian informasi sendiri. Teknologi yang dipakai dalam penyampaian informasi yang sering dipakai di tempat-tempat umum adalah menggunakan papan pesan running text (notice board). 
Papan running text terdiri dari serangkaian LED yang tersusun rapi antara baris dan kolomnya yang di program sehingga dapat menuliskan karakterkarakter yang diinginkan. Penulisan teks yang akan dikirim ke running text saat ini mengandalkan peranti komputer ataupun remote control. Peranti komputer akan dihubungkan dengan kabel ke running text sehingga harus tersedia komputer di dekat tampilan running text, sedangkan remote memiliki jarak yang terbatas dengan running text sendiri. Remote tidak dapat digunakan ditempat yang jauh.

Pada makalah ini dirancang sistem penulisan teks dengan memanfaatkan jaringan seluler GSM sebagai media pengiriman teks jarak jauh berbasis SMS. Dengan memanfaatkan modul GSM sebagai transceiver dan mikrokontroller sebagai pengolah data maka penulisan jarak jauh pun dapat dilakukan. Penulisan teks tidak lagi harus berada di dekat papan running text melainkan dapat dilakukan dipusat informasi yang berada jauh dari lokasi running text.

Penelitian ini bertujuan meningkatkan efisiensi penulisan teks pada running text dengan memanfaatkan layanan SMS. Untuk melakukan penulisan teks ke tampilan running text dapat dilakukan dari jarak jauh, dimanapun dan kapanpun tanpa harus berada dekat dengan running text tersebut. Sehingga diharapkan dapat menghemat waktu bagi pusat informasi untuk menyebarkan informasi ke beberapa lokasi running text. Selain itu, diharapkan hasil penelitian ini dapat menjadi bahan acuan untuk penerapan system komunikasi memanfaatkan jaringan GSM pada implementasi dan kegunaan yang beragam.

\section{KERANGKA TEORI}

SMS merupakan suatu mekanisme penyampaian pesan singkat pada jaringan komunikasi bergerak. Sistem ini menyimpan dan meneruskan pengiriman pesan ke dan dari perangkat komunikasi bergerak. Pesan dari pengirim disimpan di SMS center yang selanjutnya diteruskan ke perangkat penerima. Setiap pesan singkat tidak bisa lebih dari 160 karakter [1]. Jaringan GSM terdiri dari tiga sistem utama yaitu Switching System (SS), Base Station System (BSS), dan Operation and Support System (OSS). Adapun komponen jaringan GSM ditunjukkan pada Gambar 1.

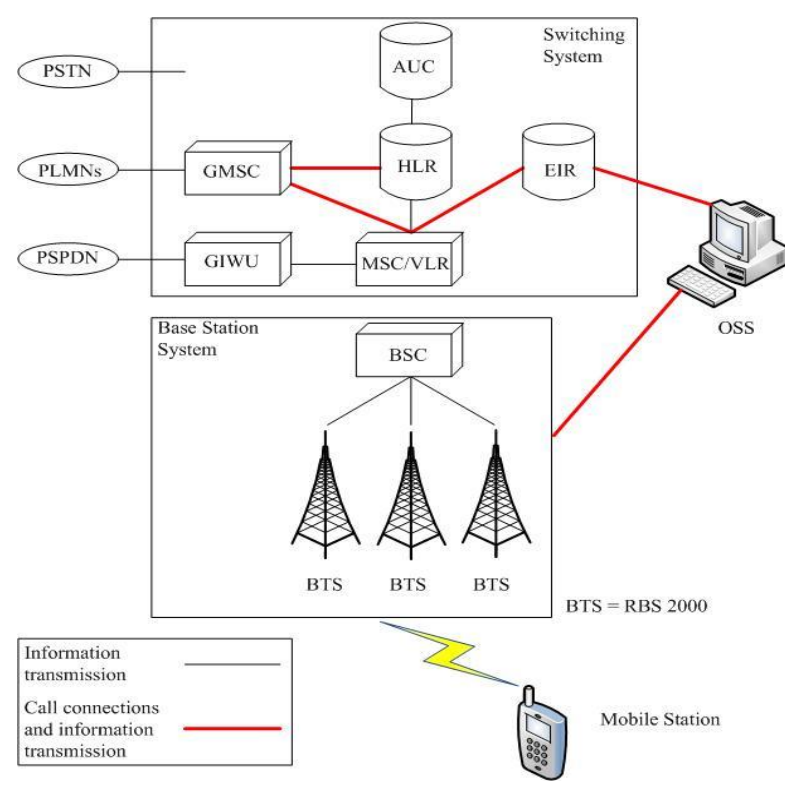

Gambar 1. Komponen Jaringan GSM [2]

Modem GSM adalah perangkat utama untuk mengirimkan dan menerima SMS secara nirkabel. Perangkat ini mengurusi proses, mulai dari mengetik pesan sampai diproses dalam jaringan GSM. Terdapat dua mode dalam SMS yaitu mode text dan mode PDU (Protocol Description Unit). Format PDU merupakan penyampaian informasi dalam biner 7 atau 8 bit. PDU merupakan informasi yang terkompres dengan pola encode tertentu, sehingga informasi yang dikirimkan oleh handphone tidak dapat langsung dibaca, tetapi harus diterjemahkan dengan aturan tertentu [3].

Salah satu cara untuk dapat menggunakan teknologi SMS pada HP adalah dengan memanfaatkan AT Command. Terdapat 16 AT command yang terkait dengan SMS. Format umum perintah baca SMS yaitu $\mathrm{AT}+\mathrm{CMGL}=\langle$ number $\rangle$, number merupakan pilihan antara 0 dan 4 , dimana 0 untuk SMS baru (inbox), 1 untuk SMS yang diterima, 2 untuk SMS yang belum dikirim (draft), 3 untuk SMS yang dikirim, 4 untuk semua SMS yang ada di memori hand phone. Informasi yang akan ditampilkan di display diterima dari HP-penerima dalam format PDU. Supaya dapat ditampilkan ke display maka data tersebut harus diubah kebentuk ASCII. Selanjutnya mikrokontroler akan menampilkan setiap karakter tersebut satu persatu dengan cara scanning baris [4]. 


\section{PERANCANGAN SISTEM}

Sistem penulisan teks pada display running text melalui SMS terdiri dari perangkat LED display dot matriks, shift register, mikrokontroller, modul GSM, dan hanphone sebagai pengirim SMS. Running text merupakan LED display dot matrik, dengan pengendalian LED yang menyala pada titiktitik yang dinyalakan dapat menghasilkan karakterkarakter huruf dan symbol yang diinginkan. Shift register berfungsi sebagai pengendali nyala LED yang akan membentuk teks, karena jika tanpa shift register nyala LED akan bersamaan dalam 1 baris ataupun 1 kolom.

Modul GSM berfungsi sebagai transceiver (transmitter dan receiver). SMS akan dikirimkan dan diterima oleh modul GSM. Selanjutnya pesan tersebut akan dikirimkan ke mikrokontroller. Kemudian mikrokontroller akan memberi perintah kepada modul GSM untuk mengirimkan laporan berupa SMS kepada pengguna bahwa teks telah di tampilkan pada running text. Fungsi mikrokontroler dalam sub sistem ini adalah memisahkan isi SMS dari informasi lainnya dan hanya mengambil isi SMS-nya. Selanjutnya isi SMS tersebut diubah ke kode ASCII, dan dari kode ASCII diubah menjadi kode dot-matrix. Proses komunikasi antara HP dan mikrokontroler difasilitasi melalui port serial RS232 dan diatur dengan AT-Command.

Seperti pada Gambar 2, gambaran umum pengisian teks pada running text dilakukan menggunakan SMS dari handphone pengguna, kemudian diterima oleh modul GSM dan diteruskan mikrokontroller untuk diolah agar menyesuaikan antara karakter yang diterima dengan running text yang digunakan.

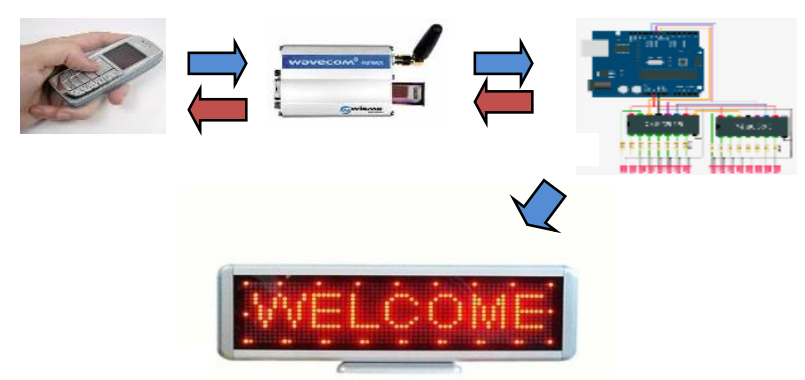

Gambar 2. Gambaran umum sistem kerja running text memanfaatkan jaringan GSM.

Setelah mikrokontroller mengkonversi teks, maka teks siap dikirim melalui register shift ke running text display. Jika pengiriman berhasil maka mikrokontroller memberi perintah kepada modul GSM untuk memberi laporan berhasil kepada pengguna berupa SMS.

Rancang bangun perangkat terbagi menjadi dua bagian, yaitu perangkat display running text dan perangkat komunikasi modul GSM seperti ditunjukkan pada Gambar 3. Rancang bangun perangkat display running text meliputi:

1. Perancangan sistem minimum ATMega, untuk menyimpan program dan sebagai pengendali terhadap keluaran yang diinginkan.

2. Perancangan interface LED Dot Matix dengan mikrokontroller. LED akan menampilkan pesan yang akan dikirimkan melalui SMS.

3. Perancangan shift register, untuk menampilkan tulisan pad LED yang akan bergeser sehingga membentuk tulisan yang berjalan (running text).

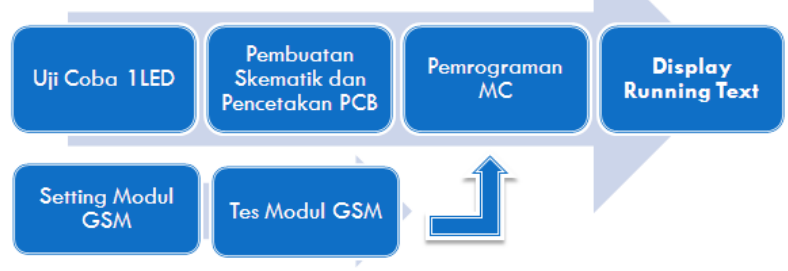

Gambar 3. Skema Perancangan Perangkat

Sedangkan rancang bangun perangkat komunikasi modul GSM meliputi perancangan interface GSM dengan mikrokontroler, untuk membaca karakter dari pesan SMS yang akan ditampilkan pada display LED dot matrix. Perancangan perangkat keras dan perangkat lunak terlebih dahulu disimulasikan menggunakan software, yakni sebelum program diimplementasikan (di upload) secara langsung pada perangkat keras.

\section{Peracangan Perangkat Keras}

Display LED Dot Matrix pada umumnya terbentuk oleh beberapa LED yang berbentuk "Dot" yang disusun membentuk matriks 5 kolom dan 7 baris $(5 \times 7)$ dan 8 kolom dan 8 baris $(8 \times 8)$ atau dengan ukuran yang lainya. Mikrokontroler merupakan sirkuit terintegrasi yang digunakan sebagai IC control yang memiliki memori sendiri sebagai penyimpanan program dan datanya. DI-Smart AVR System adalah sebuah modul elektronika yang berdasar pada rangkaian sistem minimum mikrokontroler AVR. Modul ini dapat digunakan sebagai sistem minimum mikrokontroler AVR lain yang pin-pin-nya bersesuaian dengan 
mikrokontroler ATMEGA8535, seperti mikrokontroler ATMEGA16 dan mikrokontroler ATMEGA32. Modul sistem minimum mikrokontroler AVR ini telah dilengkapi dengan beberapa fitur yang dapat mempermudah proses pembelajaran atau proses "troubleshooting" pemrograman.

\section{Peracangan Perangkat Lunak}

Compiler merupakan program yang digunakan untuk merubah bahasa assembly menjadi bahasa mesin, salah satunya adalah CodevisionAVR yang digunakan pada penelitian ini. CodevisionAVR merupakan software C-Cross compiler dimana program dapat ditulis dalam bahasa C. Codevision memiliki IDE (Integrated Development Environtment) yang lengkap, dimana penulisan program, compile, link, pembuatan kode mesin (asembler) dan download program ke chip AVR dapat dilakukan pada codevision. Selain itu juga terdapat fasilitas terminal untuk melakukan komunikasi serial mikrokontroller yang sudah diprogram [5].

\section{HASIL DAN PEMBAHASAN}

Tahapan uji coba telah dilakukan pada saat perancangan perangkat display LED Dot Matrix. Setelah berhasil menampilan karakter huruf atau angka yang sesuai pada display sebagai running text maka tahapan selanjutnya adalah uji coba komunikasi via SMS menggunakan modul GSM.

Pada tahap perancangan ini dilakukan beberapa kali pengujian, yakni pengujian IC 74HC595, pengujian untuk menampilkan teks, dan teks berjalan. Selanjutnya uji coba dilakukan secara langsung untuk menampilkan huruf atau karakter yang diinginkan pada LED Dot Matix. Pada pengujian ini diuji coba untuk text bergerak menggunakan shift register.

Setelah uji coba untuk menampilkan teks berjalan berhasil, perangkat dikemas dalam satu box untuk menjadikan satu perangkat display running text. Perangkat display running text dan perangkat Modul GSM disusun dalam satu kemasan ditunjukkan pada Gambar 4 dan Gambar 5.

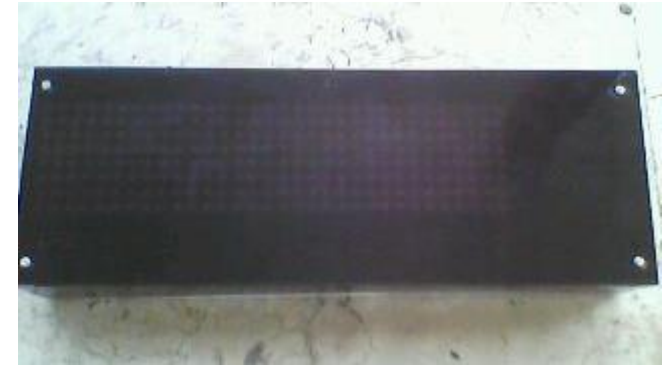

Gambar 4. Box tampak atas-depan

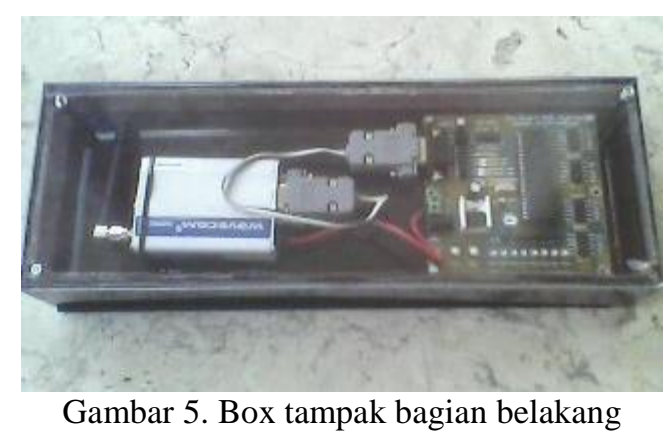

Uji coba selanjutnya adalah menampilkan teks pada display running text. Gambar 6 adalah tampilan uji coba display dengan input karakter dari komputer. Pada Gambar 7 ditunjukkan tulisan yang telah berhasil di tampilkan pada display running text.

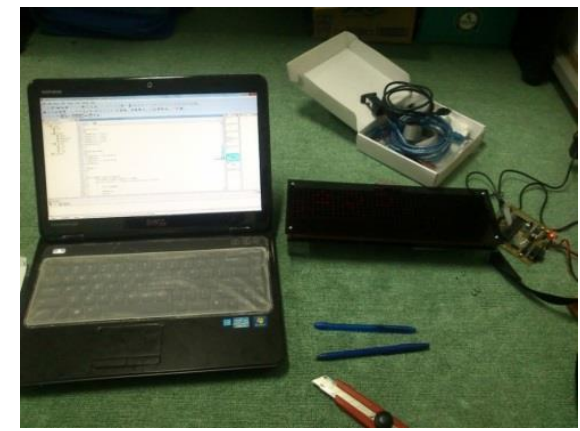

Gambar 6. Uji Coba Display dengan input karakter dari PC komputer

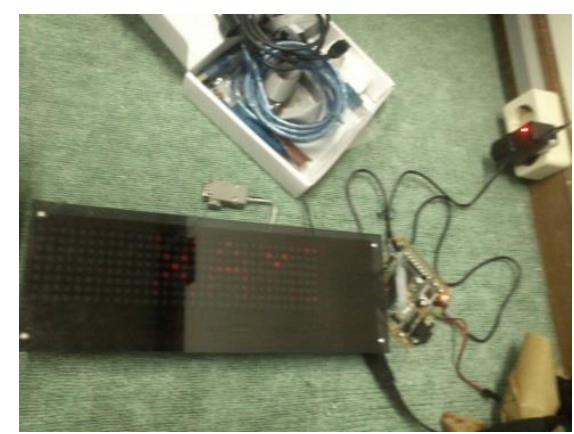

Gambar 7. Uji Coba display running text 
Pada percobaan ini telah diuji coba display running teks berjalan dengan kecepatan \pm 1 karakter/1s, berseger dari kanan ke kiri. Pada saat setting awal, kecepatan penampilan teks dapat disesuaikan, begitu juga untuk arah berjalannya teks. Karakter maksimal yang dapat ditampilkan atau diinputkan adalah 160 karakter karena mengikuti jumlah maksimal karakter yang dapat dibawa dalam satu kali SMS. Adapun ringkasan hasil uji coba sistem terdapat pada Tabel 1.

Tabel 1. Hasil Uji Coba Perangkat

\begin{tabular}{|c|c|c|}
\hline \multicolumn{2}{|r|}{ Spesifikasi } & Nilai \\
\hline \multicolumn{2}{|c|}{ Kecepatan Running Text } & $\begin{array}{l} \pm 1 \text { karakter/1s (dapat } \\
\text { disesuaikan) } \\
\text { Bergeser dari kanan ke kiri }\end{array}$ \\
\hline \multicolumn{2}{|c|}{ Maximal Karakter } & 160 karakter (SMS) \\
\hline \multirow[t]{3}{*}{ Waktu Respon } & Uji Coba 1 LED & $<1 \mathrm{~s}$ \\
\hline & Uji Coba 4 LED dari PC & $\pm 1 \mathrm{~s}$ \\
\hline & $\begin{array}{l}\text { Uji Coba } 4 \text { LED dengan } \\
\text { Modul GSM }\end{array}$ & $\pm 3 \mathrm{~s}$ \\
\hline
\end{tabular}

Uji coba selanjutnya adalah menghitung waktu respon mulai dari SMS dikirim sampai pesan ditampilkan. Uji coba dilakukan dengan menggunakan operator yang sama dan berbeda antara ponsel pengirim pesan dan operator GSM modul. Adapun hasil uji coba sebanyak 9 kali percobaan ditunjukkan pada Tabel 2 dan Tabel 3.

Tabel 2. Waktu pengiriman untuk sama operator

\begin{tabular}{cccc}
\hline $\begin{array}{c}\text { Percobaan } \\
\text { Ke- }\end{array}$ & $\begin{array}{c}\text { Panjang } \\
\text { Karakter }\end{array}$ & $\begin{array}{c}\text { Waktu } \\
\text { Sending } \\
\text { to } \\
\text { Display } \\
\text { (detik) }\end{array}$ & $\begin{array}{c}\text { Status } \\
\text { Pengiriman }\end{array}$ \\
\hline 1 & 20 & 20,79 & OK \\
\hline 2 & 40 & 22,47 & OK \\
\hline 3 & 60 & 24,33 & OK \\
\hline 4 & 80 & 26,14 & OK \\
\hline 5 & 100 & 28,07 & OK \\
\hline 6 & 120 & 30,39 & OK \\
\hline 7 & 140 & 34,85 & OK \\
\hline 8 & 160 & 39,45 & OK \\
\hline Rata rata & $\mathbf{2 8 . 3 1}$ & \\
\hline 9 & $>160$ & $1 \mathrm{~m}$ & $\begin{array}{c}\text { Display } \\
\text { Error }\end{array}$ \\
\hline \multicolumn{5}{c}{08,760}
\end{tabular}

Tabel 3. Waktu Pengiriman untuk beda operator

\begin{tabular}{cccc}
\hline $\begin{array}{c}\text { Percobaan } \\
\text { ke- }\end{array}$ & $\begin{array}{c}\text { Panjang } \\
\text { Karakter }\end{array}$ & $\begin{array}{c}\text { Waktu } \\
\text { Sending } \\
\text { to } \\
\text { Display } \\
\text { (detik) }\end{array}$ & $\begin{array}{c}\text { Status } \\
\text { Pengiriman }\end{array}$ \\
\hline 1 & 20 & 23,93 & OK \\
\hline 2 & 40 & 24,85 & OK \\
\hline 3 & 60 & 25,55 & OK \\
\hline 4 & 80 & 27,29 & OK \\
\hline 5 & 100 & 30,98 & OK \\
\hline 6 & 120 & 36,51 & OK \\
\hline 7 & 140 & 37,76 & OK \\
\hline 8 & 160 & 42,78 & OK \\
\hline Rata rata & $\mathbf{3 1 . 2 0}$ & \\
\hline 9 & $>160$ & $1 \mathrm{~m}$ & $\begin{array}{c}\text { Display } \\
\text { Error }\end{array}$ \\
\hline
\end{tabular}

Dari hasil uji coba, system penulisan jarak jauh via SMS dengan operator yang sama, untuk mengirimkan pesan 20 sampai 160 karakter memerlukan waktu rata rata 28.31 detik. Sedangkan dengan menggunakan operator yang berbeda, untuk mengirimkan pesan 20 sampai 160 karakter memerlukan waktu rata rata 31.20 detik.

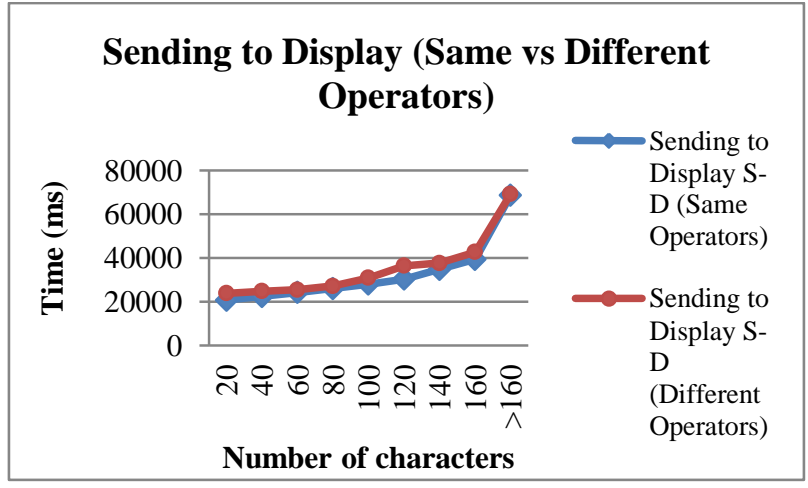

Gambar 8. Grafik perbandingan menggunakan sama operator dan beda operator

Data hasil uji coba pada tabel dirangkum pada grafik pada Gambar 8, dari grafik dapat dibandingkan bahwa ketika menggunakan beda operator, diperlukan waktu yang lebih lama untuk memproses pesan, mulai dari SMS dikirimkan sampai pesan ditampilkan pada display running 
teks. Hasil uji coba juga menunjukkan bahwa system tidak dapat memproses pesan dengan jumlah karakter lebih dari 160 karakter.

\section{KESIMPULAN}

Perancangan sistem penulisan running teks dari jarak jauh menggunakan SMS telah berhasil diimplementasikan dan diuji coba telah berhasil menampilkan teks berjalan menggunakan mikrokontroler ATMEGA8535. Rata - rata waktu pengiriman teks menggunakan operator yang sama adalah sekitar 28.31 detik dan bila menggunakan operator yang berbeda adalah sekitar 31.20 detik. Sistem penulisan teks akan semakin cepat apabila digunakan operator GSM yang sama pada ponsel dan modul GMS di sisi display running text. Diharapkan dari hasil rancangan ini dapat mempermudah penginputan teks, dan lebih efisien untuk jenis informasi yang sering berubah/diupdate serta untuk jenis informasi yang akan di broadcast ke beberapa lokasi running text secara bersamaan.

\section{DAFTAR PUSTAKA}

[1] K. Amri and T. Ceglarek, Communication Networks - SMS: How Does It Works?, May 19th, 2014.

[2] "Introduction to GSM, the Global System for Mobile Communication", 2014, [online]. Available: http://www.gsmfavorites.com/documents/introducti on/mobile/ [Accesssed May 19th, 2014].

[3] D. Apdilah dan Lukman Hakim, Running text Dengan Mikrokontroller AT89S51.

[4] B. J. Pratida, Perancangan Display LED Dot Matrix menggunakan Mikrokontroler ATmega32, Jurusan Teknik Elektro, Fakultas Teknik, Universitas Tanjungpura Pontianak.

[5] H. Supriyono dan Jatmiko, "Pengembangan Tulisan Berjalan (running text) Pada Dot Matriks Dengan Penglslan Karakter Berbasis Layanan Short Message Services (SMS) Jaringan GSM", Jurnal Teknik Gelagar, Vol. 19, No. 01, April 2008, p. 2432, 2008. 